\title{
Nanomaterials in the power engineering industry: market trends and application prospects
}

\author{
Elena Inshakova ${ }^{1,},{ }^{*}$, and Agnessa Inshakova ${ }^{2}$ \\ ${ }^{1}$ Volgograd State University, Department of Economic Theory, International and Regional Economy, \\ 400062 Volgograd, Russia \\ ${ }^{2}$ Volgograd State University, Department of Civil and International Private Law, 400062 Volgograd, \\ Russia
}

\begin{abstract}
The increase in the global consumption of marketed energy from all fuel sources (except coal) is regarded as a key factor driving power engineering industry (PEI) market growth. The absence of radical change in the structure of investment in PEI until 2030, with domination of investing equipment for the thermal power industry (with the exception of the year 2020) along with the essential growth of investment in the nuclear power industry is stated in the article. The authors focus on the significant potential of nanomaterials development and application for providing the PEI growth based on the new technological solutions and optimized technologies. Most widely used nanomaterials in the PEI worldwide, major fields and promising areas of nanomaterials application in the industry aimed at improving technology of the equipment's fuel and structural elements construction, increasing efficiency of existing equipment, and developing renewable energy sector are examined. Contemporary trends and prospects for the PEI selected nanomaterials markets, their key players, positive and negative factors of market growth are identified.
\end{abstract}

\section{The growing global energy consumption as a driver for the power engineering industry market growth}

The increase in the global energy consumption is a key factor driving power engineering industry market growth. Power engineering industry (PEI) includes production of machinery and equipment for the generation and transmission of electrical energy, as well as for the other branches of the fuel and energy sector (oil and gas and mining machinery).

According to the International Energy Outlook 2017 estimates, the 28\%-increase in the global energy consumption is expected in the period 2015-2040 - from 575 quadrillion to 736 quadrillion Btu [1]. The largest contributors to the world's energy consumption growth will be the non-OECD countries with strong, steady long-term economic growth that induces significant increase in the energy demand. Non-OECD Asian countries (first of all China and

\footnotetext{
${ }^{*}$ Corresponding author: inshakovaei@,volsu.ru
} 
India) will account for more than a half of the world's total increase in energy consumption over the estimated period.

The U.S. Energy Information Administration experts forecast increased world consumption of marketed energy from all fuel sources (with the exception of coal) through 2040. Global consumption of renewable energy will increase by an average $2.3 \%$ per year, of the nuclear energy - by $1.5 \%$ per year, and natural gas consumption - by $1.4 \%$ per year over that period.

In spite of the fact that consumption of nonfossil fuels is expected to grow faster than the fossil ones, the latter will account for $77 \%$ of energy consuming in 2040 . Natural gas is considered to be the fastest-growing fossil fuel in the International Energy Outlook 2017 forecast. Nonetheless, the share of the liquid fuels in the world marketed energy consumption will reduce from $33 \%$ in 2015 to $31 \%$ in 2040, being an expected result of adopting energyefficient technologies and an attempt to replace liquid fuels consuming by many national energy users.

World net electricity generation increases by $45 \%$ in $2015-2040$. Electricity will remain the world's fastest-growing form of end-use energy consumption.

Nuclear electricity generation will rise from 2.5 trillion $\mathrm{kWh}$ in 2015 to 3.2 trillion $\mathrm{kWh}$ by 2030 and to 3.7 trillion $\mathrm{kWh}$ by 2040 .

All net expansion in the worldwide installed nuclear power capacity is expected in nonOECD countries with the strong China's leadership from 2015 to 2040.

Taking into consideration the above mentioned trends in the world energy consumption, the growth of the global power engineering industry market is not surprising. The global PEI market has accounted for nearly USD 110 billion in 2016 (USD 100 billion in 2013), and is expected to reach USD 150 billion per year by 2030. The PEI market structure from the point of view of the structure of investment in the main industry sectors has been presented at Fig. $1[2]$.

The data at Fig. 1 demonstrate the absence of expectations of the radical change in the structure of investment in PEI until 2030, and domination of investing equipment for the thermal power industry (with the exception of the year 2020) along with the essential growth of investment in the nuclear power industry.

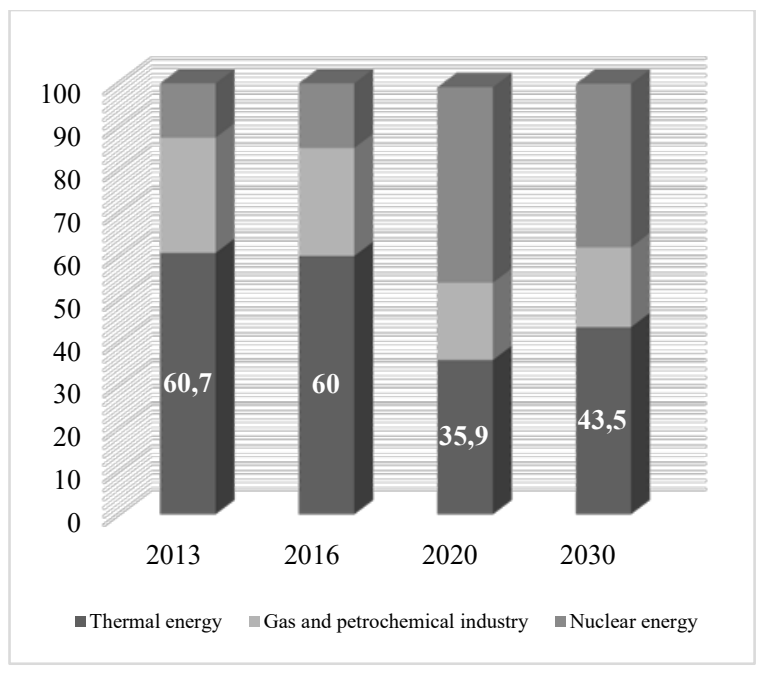

Fig. 1. Current and forecasted structure of the global power engineering industry market (percentage).

Countries - the global leaders in the nuclear energy production by the number of the nuclear power plants' operable nuclear reactors can be seen at Fig. 2 [3]. 


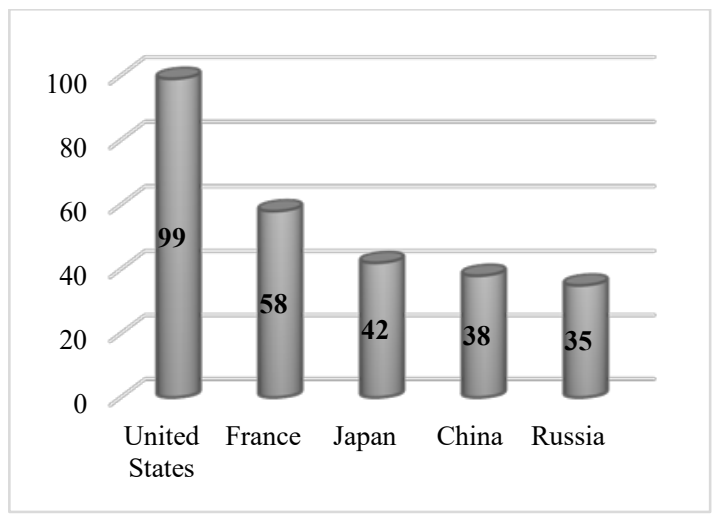

Fig. 2. The number of the nuclear power plants' operable nuclear reactors by countries, 2017 (units).

The situation in the Russian PEI market largely corresponds to the global one: $60 \%$ of investments have been directed in equipment for thermal power generation, $29 \%$ - in equipment for gas and petrochemical industry, and $11 \%$ - in equipment for nuclear energy [2]. For the previous 6 years the domestic PEI production increased by 36\%, exports increased 2.6 times, imports decreased by $10 \%$ (from 62 to 52\%). Production in the gas and petrochemical equipment industry increased by $39 \%$.

The current Russian PEI market is estimated as RUB 350 billion per year. Its three largest players account for $68 \%$ of the market, including the Machine Building Division of the State Atomic Energy Corporation Rosatom (27\% of the industry market). The average annual growth of the domestic PEI market until 2030 will be within 1-2\%, and growth of competition among producers and reduction of imports of energy equipment and its components [4] as the predominant industry market trends have been forecasted.

\section{Nanomaterials development and application in the power engineering industry: potential for the industry growth}

The need to develop power engineering industry based on the increase of global energy consumption, on one hand, and growing technological complexity along with the growing costs of energy generation, transmission and storage, on the other hand, have significantly accelerated application of advanced materials and technologies, including nanomaterials and nanotechnologies, in the industry.

This statement can be proved by the fact of growth for the period 2015-2017 of a number of the European Patent Office (EPO) patent applications for technology field "Electrical machinery, apparatus, energy", which has been ranked $4^{\text {th }}$ among 10 technology fields with the largest number of applications in 2017 (Fig. 3) [5].

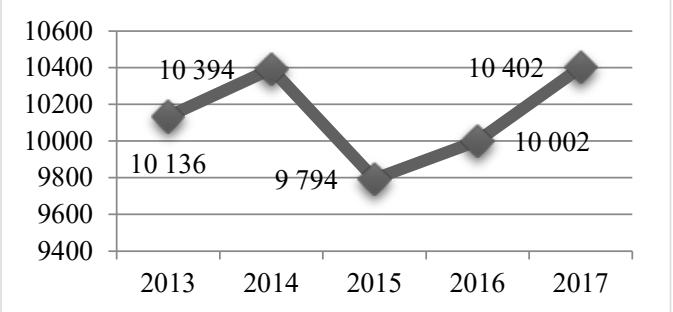

Fig. 3. Dynamics of the EPO patent applications for the technology field "Electrical machinery, apparatus, energy" (units). 
One can see that a group of leading countries - Germany, Japan and United State account for $54,6 \%$ of the total number of EPO patent applications for the technology field under consideration, and for $58,9 \%$ of the total granted patents (Table 1) [5]. That is why the steady presence of their national companies (Siemens, Caterpillar, Cummins Power Systems, Sawafuji, Generac, Honda Power, etc.) among the main players on the global power generation equipment market is understandable [6].

Production application of nanomaterials and nanotechnologies provide novel opportunities for the development either conventional or renewable energy sources based on the new technological solutions and optimized technologies of energy generation, conversion, transmission, distribution, and storage.

Table 1. EPO patent applications (PA)* and granted patents (GP) by technology field "Electrical machinery, apparatus, energy", selected countries (units)

\begin{tabular}{|c|c|c|c|c|c|c|c|c|c|c|}
\hline \multirow[t]{2}{*}{ Country } & \multicolumn{2}{|c|}{2013} & \multicolumn{2}{|c|}{2014} & \multicolumn{2}{|c|}{2015} & \multicolumn{2}{|c|}{2016} & \multicolumn{2}{|c|}{2017} \\
\hline & PA & GP & PA & GP & PA & GP & PA & GP & PA & GP \\
\hline Austria & 192 & 78 & 203 & 72 & 227 & 122 & 210 & 159 & 224 & 168 \\
\hline Belgium & 68 & 20 & 73 & 23 & 107 & 30 & 91 & 48 & 96 & 42 \\
\hline Switzerland & 515 & 183 & 516 & 253 & 513 & 282 & 495 & 358 & 483 & 367 \\
\hline Germany & 2119 & 909 & 2075 & 951 & 1817 & 1184 & 1870 & 1609 & 1966 & 1707 \\
\hline Denmark & 86 & 28 & 86 & 31 & 67 & 36 & 73 & 50 & 76 & 49 \\
\hline Spain & 67 & 16 & 61 & 22 & 50 & 27 & 73 & 35 & 129 & 40 \\
\hline Finland & 72 & 26 & 97 & 23 & 105 & 30 & 79 & 44 & 77 & 53 \\
\hline France & 574 & 317 & 652 & 318 & 623 & 423 & 675 & 519 & 698 & 582 \\
\hline United Kingdom & 290 & 96 & 337 & 133 & 266 & 131 & 269 & 156 & 261 & 194 \\
\hline Italy & 173 & 104 & 161 & 138 & 173 & 134 & 183 & 139 & 180 & 152 \\
\hline Netherlands & 461 & 114 & 626 & 113 & 614 & 151 & 640 & 257 & 619 & 302 \\
\hline Sweden & 93 & 29 & 102 & 40 & 89 & 33 & 105 & 68 & 98 & 68 \\
\hline Canada & 56 & 42 & 49 & 35 & 39 & 32 & 58 & 37 & 55 & 44 \\
\hline P.R. China & 236 & 33 & 250 & 53 & 274 & 58 & 396 & 136 & 570 & 157 \\
\hline Japan & 2431 & 776 & 2198 & 791 & 1939 & 880 & 1811 & 1336 & 1952 & 1767 \\
\hline R. Korea & 672 & 278 & 793 & 278 & 669 & 331 & 811 & 488 & 613 & 685 \\
\hline Chinese Tapei & 116 & 37 & 119 & 46 & 115 & 27 & 165 & 54 & 120 & 79 \\
\hline United States & 1596 & 544 & 1639 & 572 & 1749 & 617 & 1614 & 1035 & 1735 & 1107 \\
\hline Total & 10136 & 3701 & 10394 & 3996 & 9794 & 4646 & 10002 & 6705 & 10402 & 7776 \\
\hline
\end{tabular}

* - European patent applications include direct European applications and international (PCT) applications that entered the European phase during the reporting period.

Mostly used nanomaterials in the PEI worldwide are as following: carbon nanostructures (including graphene, fullerenes), organic and inorganic materials with the nanolayer and cluster-fractal structure, metal oxide nanoparticles, nanocomposite coatings resistant to the radiation effects.

Nanomaterials application in the power engineering industry [7-10] is aimed at improving technology of construction of the equipment's fuel and structural elements, increasing efficiency of existing equipment, and developing renewable energy sector in the following fields:

- energy absorption and storage based on carbon nanostructures usage;

- significant increase of solar cells efficiency based on the new possibilities of energy accumulation and transfer in the inorganic and organic materials with the nano-layer and cluster-fractal structure;

- creating the electrodes with a developed surface for the hydrogen energy needs based on the use of the track-etched membranes; 
- creating the heat-resistant parts of turbines to increase the efficiency of converting one type of energy into another based on the use of the heat-resistant gradient titanium-containing nanocoatings;

- construction of the fuel-emitting and neutron-absorbing elements of nuclear reactors based on the use of the radiation resistant nanocomposite coatings;

- providing environment protection in the process of the irradiated nuclear fuel's storage and recycling, as well as managing the quality of the nuclear systems assembly and operation, based on the nanosensors use;

- separation processes in the nuclear fuel fabrication and reprocessing based on the nanofilters use.

Whereas the integrated principal aim of nanomaterial application in PEI is to provide efficiency growth [9] for producers and consumers of the industry production, the promising areas of applying nanomaterials cover:

conversion of primary energy sources into electricity, heat and kinetic energy;

construction of the wear, heat-resistant, lightweight construction and corrosion protection materials for the oil and natural gas deposits development, and for the geothermal, wind and tide power energy generation and climate-neutral storage;

reduction of carbon dioxide emissions at the fossil-fired gas and steam power plants;

reduction of energy losses in current energy transmission;

provision of complex control and monitoring of the large-scale energy grids;

avoiding unnecessary energy consumption in all branches of industry and households with contributing to the cconsiderable energy savings.

\section{Contemporary market trends for selected nanomaterials applicable in the power engineering industry}

The main factor driving growing PEI demand on the nanocomposite coatings is directly connected to their supreme characteristics including multiplied mechanical strength, heat, wear, scratch resistance and weight reduction [10]. Besides the nuclear power engineering, nanocomposite coatings can get efficient application in the other areas of the energy equipment functioning under extreme heat and wear conditions: in steam turbines of thermal power plants, for example.

A fundamentally new approach to creating advanced nanocomposite coatings, which are resistant to radiation exposure and can be widely used in the nuclear reactors and spacecraft engineering, is developed by the scientists from Tomsk Polytechnic University (Russia), Czech and Belarus universities [11]. Yttrium oxide nanoparticles are used there in the thirdgeneration nuclear reactors to absorb radiation vacancies - «cavities» as a result of irradiation. Thus, the material's swell is prevented, and reactor can be reloaded much less frequently. Nanocomposite materials will be widely utilized in the nuclear reactors of the fourth generation.

Top manufacturers in the global yttrium oxide nanoparticle market are: American Elements, Nanoshel LLC, Meliorum Technologies Ltd, Nanostructured \& Amorphous Materials, Inc, Nanophase Technologies Corporation, Showa Denko K.K. [12].

Factors of the metal oxide nanoparticles (also referred to as nanopowders or nanocrystals) market growth are the following ones: diversity of functional, consequently of applicational, opportunities (thermal barrier, anti-corrosion, utilization in friction units of almost all types of equipment) due to the their superior chemical, electronic and magnetic properties. Restraining factors for the market growth are: slowing world economy growth as well as maturity of a number of big end-user markets for metal oxide nanoparticles worldwide. Metal oxide nanoparticles market is expected to grow at a compound annual growth rate (CAGR) 
of $10.5 \%$ [13]. Even with a pessimistic scenario of market development almost six times increase (by 1,663,168 tons) is expected in the period 2012-2020 [14].

North America is considered to remain the biggest market for metal oxide nanoparticles (with the market share of more than $60 \%$ by 2022 [13]) - as a result of such factors as high availability of raw materials for oxide production; large scale US federal government support for nanotechnology development and production application in the National Nanotechnology Initiative framework. Key players in this market: Altair Nanomaterials, Eprui Nanoparticles \& Microspheres Co. Ltd., NanoScale Corporation, Reinste Nanoventures, Sigma Aldrich, US Research Nanomaterials Inc. Aggressively growing competition in this market will induce upcoming increase in the R\&D and innovation activity along with M\&A.

Nano titanium dioxide market has been estimated at about USD 4.5 billion in 2015, and is expected to reach USD 16,7 billion by 2022 , backed by a CAGR of $20.7 \%$ [15]. China, Germany, and U.S. led the global nano titanium dioxide market in 2015. High market demand for nano titanium dioxide is forecasted in Europe, United States, emerging economies such as China, India, and some other countries. The factors supporting this market significant growth in the near future: diversity of applications, government support for R\&D in order to find new commercialization channels. Factors restraining the market: toxicity at a certain amount, and high production cost. Asia-Pacific is expected to lead the market during 20162022 (with a CAGR of $21.3 \%$, compared to $20.7 \%$ CAGR for the global nano titanium dioxide market for the forecasted period) followed by Latin America, Middle East \& Africa, North America, and Europe.

Major players on the nano titanium dioxide market are Cristal, E. I. Du Pont De Nemours and Co., Evonik Industries AG, Huntsman International LLC, Nano-Oxides, Inc., NanoScale Corporation, and Tayca Corporation [15]. Significant investment in R\&D to solve the problem of expanding commercial application of nanomaterials and reducing production costs boost strategic collaborations and alliances in the industry.

It should be mentioned that carbon tubes themselves are not so importanat for the PEI future. However, a weighty positive change in the PEI performance will bring the use of macro-materials constructed from the carbon nanotubes (CNT) or containing CNT.

According to the new research report by Global Market Insights, upcoming in June 2018, carbon nanotubes market size was USD 1.35 billion in 2015, and it is expected to grow at $22.1 \%$ between 2016 and 2024 that will result in exceeding USD 8.1 billion by 2024 [16]. The experts point out an expressive rise in CNT patents over the last 5 years, which has strongly backed the growing CNT market.

From the point of view of the geografical structure of the CNT market North America and Europe are the biggest markets, accounting for its almost $70 \%$ share, while Asia-Pacific countries (with a market share of $25 \%$, and a CAGR of $49.2 \%$ in the field of nanotechnology for the energy sectors in 2014-2018) are the third biggest and fastest growing regional market for CNT. The factors driving the regional market: growing industrialisation in China and India, meaningful FDI inflow in the energy sector, and stable demand for specialised materials [17].

Some of the leading companies in the CNT market are listed below: Nanocyl S.A, Arkema S.A., CNano Technology Ltd., Bayer MaterialScience AG, Showa Denko K.K., and Hyperion Catalysis International, Inc.

The utilization of nanostructures (like quantum dots and others) in the PEI players' performane could allow for solar cell efficiency growth over $60 \%$ in the long run.

The prospects of selected PEI nanomaterials markets have been summarized in the Table $2[12,13,15-18]$. 
Table 2. Power engineering industry markets for selected nanomaterials.

\begin{tabular}{|l|c|c|c|}
\hline \multirow{2}{*}{$\begin{array}{c}\text { Selected PEI nanomaterials } \\
\text { market }\end{array}$} & \multicolumn{2}{|c|}{$\begin{array}{c}\text { Selected PEI nanomaterials market revenue, } \\
\text { USD billion }\end{array}$} & $\begin{array}{c}\text { Expected CAGR in } \\
\mathbf{2 0 1 6 - 2 0 2 1 ,} \\
\text { percentage }\end{array}$ \\
\cline { 2 - 3 } & $\mathbf{2 0 1 6}$ & $\mathbf{2 0 2 1}$ forecast & 26.7 \\
\hline Nanocomposites & 1.6 & 5.3 & 20,7 \\
\hline Nano titanium dioxide & 5.3 & 15.8 & 22.1 \\
\hline Carbon nanotubes & 1.62 & 7.3 & 8.9 \\
\hline $\begin{array}{l}\text { Advanced \& nanoscale } \\
\text { ceramic powders }\end{array}$ & 14.6 & 22.3 & 41.3 \\
\hline Quantum dots & 0.61 & 3.4 & 22.1 \\
\hline Carbon nanotubes & 1.62 & 7.3 & 8.3 \\
\hline Specialty sorbents & 0.76 & 1.2 & \\
\hline
\end{tabular}

Thereby, summarized key modern factors of the global PEI nanomaterials market growth are as following: rising research and development activities aimed at improving and expanding the product applications; stable and rapid growth in the nanotechnology based on the expanding state and corporate investment in this technology field; growing new opportunities of potential application along the value-added chain in the energy sector and across all branches of the fuel and energy complex; significant potential for increasing efficiency of the energy sector performance.

As to the major factors restraining development of the global PEI nanomaterials market (especially nanomaterials for the nuclear energy sector), they are: concerns about energy production and transmission security and greenhouse gas emissions; high production costs of advanced nanomaterials development and manufacturing along with the insufficient demand in the market under consideration; opposition from the local society that hinder the development of new nuclear generating capacities and this energy sector expanding in many regions of the world.

The reported study was funded by the Russian Foundation for Humanities according to the research project № 16-02-00591-OGN "State policy of the RF in the sphere of nanoindustry in an unfavorable external environment".

\section{References}

1. International Energy Outlook 2017 (Washington, U.S. Energy Information Administration, 2017)

2. Rosatom Annual Report, 2016 (Moscow, Rosatom, 2017)

3. Nuclear Power in the World Today (World Nuclear Association website)

4. Power engineering: some facts over 6 years. April 11, 2018 (The Russian Government website)

5. EPO Annual Report 2017 (EPO website)

6. Global power generation equipment market analysis 2011-2017 and forecast 2018-2023 (Market Updates, 2017)

7. S.M. Alfimov, V.A. Bykov, E.P. Grebennikov, et al., Development of works in the field of nanotechnologies in Russia, in nano- and microsystem technology. From research to development (Moscow, Technosphere, 2005)

8. M. Khalil, B.M. Jan, C. Wen Tong, M.A. Berawi, Applied Energy, 191 (2017)

9. Application of nanotechnologies in the energy sector (Hessian Ministry of Economics, Energy, Transport and Regional Development website.) 
10. N.Y. Abu-Thabit, A.S. Makhlouf, Recent advances in nanocomposite coatings for corrosion protection applications in Handbook of Nanoceramic and nanocomposite coatings and materials (Elsevier, 2015)

11. Radiation Resistant Nanocoatings for Nuclear Fuel, Tomsk Polytechnic University Scientists Developing (TPU website)

12. Yttrium oxide nanoparticle market analysis, growth, size, share, trends, forecast, supply, demand and sales to 2023 (Market Updates, 2017)

13. Global metal oxide nanoparticles market insights, opportunity analysis, market shares and forecast, 2017 - 2023 (Research and Markets, January 2017)

14. H. Baharvand, N. Aghdami, Stem-cell nanoengineering (John Wiley \& Sons Inc., 2015)

15. Nano titanium dioxide market by application - global opportunity analysis and industry forecast, 2014 - 2022 (Allied Market Research, 2016)

16. Carbon nanotubes market: global industry analysis and opportunity assessment 20142020 (Future Markets Insights, Inc., June 2018)

17. Carbon nanotubes market size by product, by application, industry analysis report, regional outlook, growth potential, price trends, competitive market share \& forecast, 2016-2024 (Global Market Insights, Inc., 2016)

18. Nanomaterials Market - Global Opportunity Analysis and Industry Forecast, 20142022 (Allied Market Research, September 2016) 